\title{
THE EFFECTS OF QUORUM SENSING AND TEMPERATURE ON THE SOLUBLE PROTEOME OF VIBRIO SALMONICIDA
}

\author{
A Thesis \\ presented to \\ the Faculty of California Polytechnic University, \\ San Luis Obispo
}

\author{
In Partial Fulfillment \\ of the Requirements for the Degree \\ Master of Science in Biological Sciences
}

by

Christopher Massey

June 2016 
(C) 2016

Christopher Massey

ALL RIGHTS RESERVED 
COMMITTEE MEMBERSHIP

TITLE:

The Effects of Quorum Sensing and Temperature on the Soluble Proteome of Vibrio salmonicida

AUTHOR: $\quad$ Christopher Massey

DATE SUBMITTED: June 2016

COMMITTEE CHAIR: Pat Fidopiastis, Ph.D.

Professor of Microbiology

COMMITTEE MEMBER: Christopher Kitts, Ph.D.

Professor and Department Chair of Biological Sciences

COMMITTEE MEMBER: Michael Black, Ph.D.

Professor of Microbiology

COMMITTEE MEMBER: Lars Tomanek, Ph.D.

Associate Professor of Biological Sciences 


\section{ABSTRACT}

The Effects of Quorum Sensing and Temperature on the Soluble Proteome of Vibrio salmonicida

Christopher Massey

Vibrio salmonicida causes cold-water vibriosis in salmon populations around the world and causes financial damage to fisheries designed to farm these salmon. Very little is known about the physiology of how $V$. salmonicida causes disease and measures to contain vibriosis are restricted to either vaccinating individual fish against disease or administering antibiotics when an outbreak is detected. These procedures are costly and increase the risk for selection of antibiotic-resistant $V$. salmonicida strains. A recent reoccurrence of outbreaks in Norwegian fisheries provided incentive to better understand the virulence mechanisms of $V$. salmonicida. In this thesis, a proteomic approach was used to identify proteins that were differentially expressed when cells were grown in vitro under simulated virulence conditions (i.e. $5^{\circ} \mathrm{C}$ and in the presence of exogenously supplied autoinducer 3-oxo-hexanoyl-homoserine lactone). Some examples of proteins with significantly altered expression that stood out at as homologs of potential virulence factors were: an exported serine protease DegQ, a multi-drug transporter HlyD, and an outer membrane protein OmpU. The proteomic approach allowed us to identify large numbers of proteins that are expressed by $V$. salmonicida, facilitating hypothesis-driven research in order to support possible roles for some of these proteins in virulence. 


\section{ACKNOWLEDGMENTS}

First, I would like to thank my committee chair and advisor, Pat Fidopiastis, for his patience and wisdom as I completed this thesis. Not only has he trained me to become a proficient microbiologist, but he has taught me valuable lessons about compassionate leadership and scientific responsibility.

I would also like to express a special thanks to Lars Tomanek and Marcus Zuzow for the use of the Environmental Proteomics Laboratory as well as for training in the use of equipment and techniques required to analyze the 2D soluble proteome of Vibrio salmonicida

Special thanks to Ane Mohn Bjelland and Henning Sørum from the Norwegian School of Veterinary Science in Oslo Norway for their work characterizing and elucidating the role that $\mathrm{OmpU}$ plays in the pathogenesis of Vibrio salmonocida

Finally, I owe a debt of gratitude to my parents, Eugene and Maryse Massey, as well as my wife, Kate Massey whose gentle encouragement and support gave me the inspiration I needed to complete this journey. I would not have been able to do this without you.

Chris Massey 


\section{TABLE OF CONTENTS}

LIST OF FIGURES.

Page CHAPTER

Introduction 1

Materials and Methodology. 4

Starter Cultures and Conditions 4

Luminescence Assays of lux Operon Gene Expression under Effects of Quorum Sensing and Temperature Variation.................................................................. 4

Preparation of Vibrio salmonicida Cultures for Proteomic Analysis .......................... 5

Protein Extraction and Proteomic Analysis ..................................................... 5

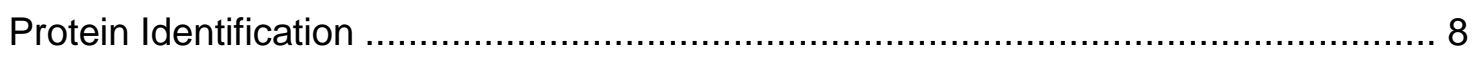

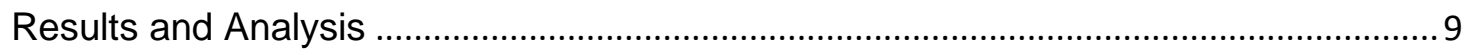

Luminescence Assay of lux Operon Gene Expression .................................... 9

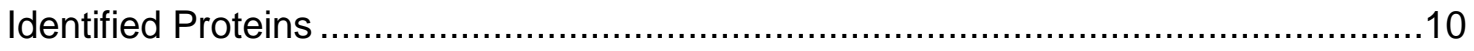

Outer Membrane Proteins ............................................................................ 10

Heat/Cold Shock Proteins and Molecular Chaperones......................................11

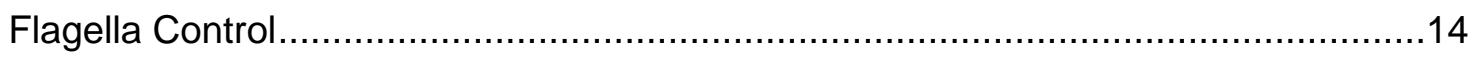

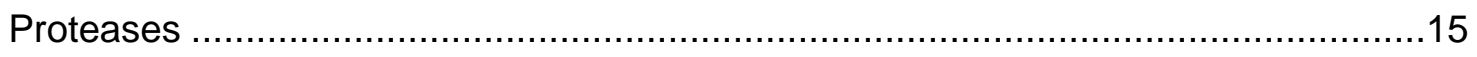

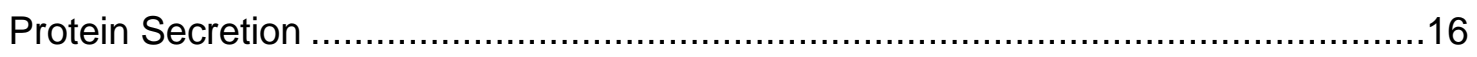

$\mathrm{N}$-Acyl Homoserine Lactone (HSL) production ..........................................17

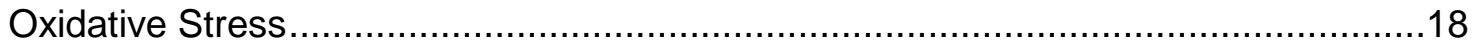

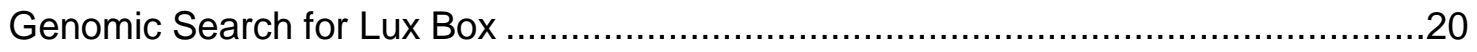

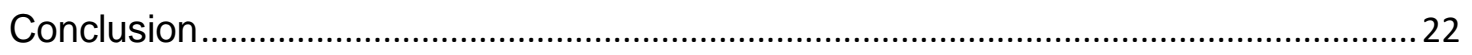

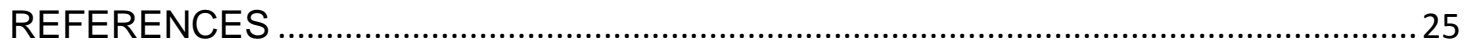

APPENDICES

Appendix I - Table of Identified Proteins and Fusion Image and Heat Map...............29

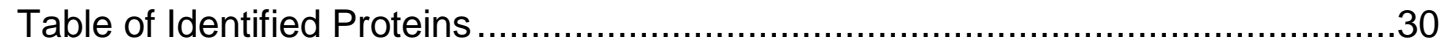

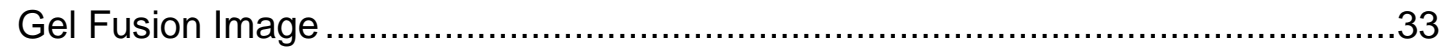

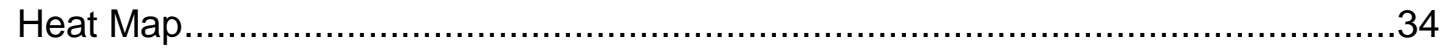

Appendix II - Related Publication - Poster, ASM General Meeting, June 2015 ........35 


\section{LIST OF FIGURES}

$\begin{array}{ll}\text { Figure } & \text { Page }\end{array}$

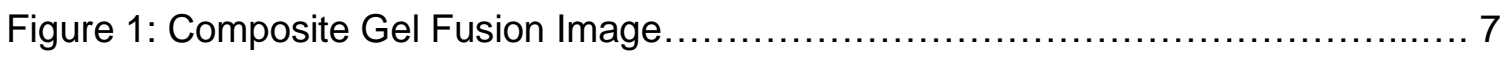

Figure 2: Temperature-Dependent Luminescence of Vibrio salmonicida at Quorum

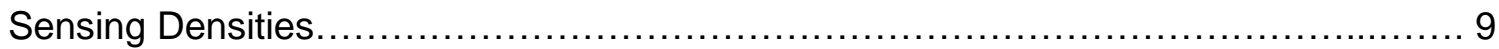

Figure 3: Regulatory pathway of heat shock proteins identified in response to

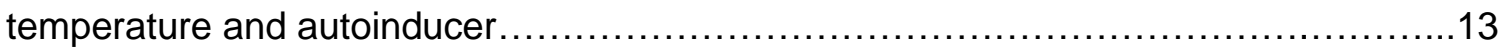

Figure 4: Detection of the Lux Box of Hypothetical Virulence-Related Proteins.......... 21 


\section{Introduction}

Vibrio (Aliivibrio) salmonicida is the causative agent of Cold Water Vibriosis (CV, or Hitra disease) affecting Atlantic salmon (Salmo salar) aquaculturei. The disease is managed through vaccination, and successful treatment involves administration of antibiotics such as florfenicoli", however, there is still much to learn about the pathogenesis of $V$. salmonicida and its associated disease mechanisms. Recent reoccurrence of outbreaks in Norwegian fisheries ${ }^{\text {iii }}$ has caused some alarm and provided a new incentive to better understand the disease causing properties of Vibrio salmonicida.

Previous attempts at understanding $V$. salmonicida virulence focused on individual genes or proteins suspected of being involved with pathogenesis. For example, the novel regulation of the lux operon (which encodes for bioluminescence and quorum sensing in Vibrio species) is associated with the ability of $V$. salmonicida to cause disease. A strain of $V$. salmonicida unable to express LuxA, one-half of the enzyme complex for luciferase that is required for luminescence, showed significantly reduced virulence, but the mutant's continued ability to cause disease indicates there are other factors involved in pathogenesisiv. Indeed, other studies have been able to isolate pieces of $V$. salmonicida's mechanism of causing disease, such as surface antigen VS-P1 ${ }^{v}$, flagellin upregulation ${ }^{\text {vi }}$ and siderophore production ${ }^{\text {vii }}$, but a complete picture of virulence remains elusive.

One interesting property of $V$. salmonicida is that it primarily causes disease when temperatures are below $10^{\circ} \mathrm{C}$, possibly confounding the results of the majority of in-vitro disease research done at the organism's optimal growth temperature of $15^{\circ} \mathrm{C}$. Therefore, it is important to do disease research at pathogenically relevant 
temperatures, especially when performing physiological experiments. Furthermore, there is also a global regulator of gene transcription in $V$. salmonicida that may be linked to virulence: quorum sensing. Quorum sensing in Vibrio species involves the release of transcriptional activators termed 'autoinducers.' These autoinducers activate a family of transcription factors that bind to regions in gene promoters called the 'lux box' (named for the lux operon where these transcription factors were first discovered to bind) to activate gene transcription. When a population of Vibrio species grows to a certain critical density, the concentration of these secreted autoinducers activate gene expression for a variety of functions. For example: in Vibrio fischeri, quorum-sensing upregulates the lux operon to induce light production, which aids in colonization of its squid host Euprymna scolopes ${ }^{\text {viii. }}$. In Vibrio cholerae, quorum sensing is considered an important precursor to the activation of virulence genes ${ }^{i x}$. Quorum sensing serves to activate and inhibit physiologically expensive processes such as virulence and bioluminescence depending upon the density of the population. Autoinducer concentration also controls several biochemical functions in $V$. salmonicida, but its effects on physiology are not completely understoodxıv.

The purpose of this study is to determine the effects of quorum sensing and cold temperatures synergistically on the physiology of $V$. salmonicida using a proteomic approach to identify expressed putative virulence factors. First, luminescence was used as an indicator for measuring the effect of quorum sensing on LuxA as previously describediv; a growth curve was performed at approximately $15^{\circ} \mathrm{C}$ and $5^{\circ} \mathrm{C}$ to see if cell density and pathogenically relevant temperatures would have an interactive effect on gene expression. At high cell densities, where quorum sensing has its greatest effects, a 30-fold increase in luminescence was observed in the $5^{\circ} \mathrm{C}$ treatment compared to the $15^{\circ} \mathrm{C}$ treatment. This indicates that expression of certain quorum sensing regulated 
genes may also be co-regulated through temperature. Next, a proteomic approach was used to identify genes that are differentially expressed as a result of a combination of pathogenically relevant temperatures $\left(5^{\circ} \mathrm{C}\right)$ and quorum sensing. In order to properly compare the effects of quorum sensing, while controlling for any confounding effects that stationary phase growth vs. log phase growth may have on the culture, cultures were grown to the same optical density $\left(\mathrm{OD}_{600}\right)$ with and without the addition of exogenous autoinducer N-3-Oxohexanoyl-L-Homoserine Lactone (OHHSL) as the stimulator of quorum sensing. The resulting protein expression profile was analyzed, and differentially expressed hypothetical virulence factors were identified. This study now lays the foundation for additional studies on the role of these proteins in V. salmonicida physiology and virulence. 


\section{Materials and Methodology}

\section{Starter Cultures and Conditions}

Vibrio salmonicida strain LF1238 isolated from diseased Atlantic salmon was used in our experiments. The complete genome of this strain was sequenced ${ }^{x \times x v}$ and can be accessed at URL- http://www.sanger.ac.uk/resources/downloads/bacteria/aliivibriosalmonicida.html. The strain was streaked on Tryptic Soy Agar plates supplemented with $1.5 \% \mathrm{w} / \mathrm{v} \mathrm{NaCl}$ (TSA 1.5). Starter cultures were prepared by inoculating Brain-Heart Infusion Broth supplemented with $1.5 \% \mathrm{w} / \mathrm{v} \mathrm{NaCl}(\mathrm{BHI} 1.5)$ with one to two isolated colonies of $V$. salmonicida and incubated overnight in a refrigerated shaking incubator set to either approximately $5^{\circ} \mathrm{C}$ or $15^{\circ} \mathrm{C}$.

\section{Luminescence Assays of lux Operon Gene Expression under Effects of Quorum Sensing and Temperature Variation}

$\mathrm{BHI} 1.5$ starter cultures were incubated at approximately $5^{\circ} \mathrm{C}$ and $15^{\circ} \mathrm{C}$ with shaking at $225 \mathrm{RPM}$ to an $\mathrm{OD}_{600}$ of 0.4 . These broth cultures were used to inoculate respective 15 $\mathrm{ml} \mathrm{BHI} 1.5$ broth cultures to a starting $\mathrm{OD}_{600}$ of approximately 0.04 to start the growth curve. At approximately every four hours, $100 \mu \mathrm{l}$ was removed from each shaking culture and measured for $\mathrm{OD}_{600}$ and luminescence with the addition of $0.005 \% \mathrm{v} / \mathrm{v}$ decyl aldehyde (Sigma Aldrich) as described previouslyiii. Luminescence emission per cell (i.e. Luminescence $/ \mathrm{OD}_{600}$ ) was plotted against $\mathrm{OD}_{600}$ of each culture for comparison. 


\section{Preparation of Vibrio salmonicida Cultures for Proteomic Analysis}

$\mathrm{BHI} 1.5$ broth cultures were incubated at $5^{\circ} \mathrm{C}$ or $15^{\circ} \mathrm{C}$ with shaking at $225 \mathrm{RPM}$ until they reached an $\mathrm{OD}_{600}$ of 0.4 . These broth cultures were used to inoculate four different $50 \mathrm{ml}$ $\mathrm{BHI} 1.5$ broth cultures to a starting $\mathrm{OD}_{600}$ of approximately 0.04 to start the growth curve. Two of the broth cultures were fortified with $200 \mathrm{nM}$ of the autoinducer N-3-OxooctanoylL-Homoserine Lactone (VAl1) to stimulate quorum sensing, and two were unfortified. Each of these conditions were incubated with shaking at $5^{\circ} \mathrm{C}$ and $15^{\circ} \mathrm{C}$ until they reached an approximate $\mathrm{OD}_{600}$ of 1.0 . The culture without autoinducer incubated at $15^{\circ} \mathrm{C}$ served as the control condition. The culture with added autoinducer incubated at $5^{\circ} \mathrm{C}$ served as the test or 'disease causing' condition to determine the effects of autoinducer and temperature simultaneously. The culture with added autoinducer incubated at $15^{\circ} \mathrm{C}$ and the culture without autoinducer incubated at $5^{\circ} \mathrm{C}$ served to identify the effects of each condition on protein expression independently. Each culture was prepared for protein extraction by centrifuging at $800 x g$ for 15 minutes at $4^{\circ} \mathrm{C}$.

\section{Protein Extraction and Proteomic Analysis}

The pellets of the four $V$. salmonicida cultures were processed for proteomic analysis as described by Tomanek and Zuzow ${ }^{\mathrm{x}}$. Pellets were re-suspended and lysed in 1:10 in homogenization buffer [7 M urea, $2 \mathrm{M}$ thiourea, 1\% ASB-14 (amidosulfobetaine-14), 40 mM Tris-base, 0.5\% immobilized pH 4-7 gradient (IPG) buffer (GE Healthcare, Piscataway, NJ, USA) and $40 \mathrm{mM}$ dithiothreitol] using a pre-chilled glass homogenizer for mechanical homogenization.

The homogenate was maintained at $20^{\circ} \mathrm{C}$ and centrifuged at $16,100 \mathrm{xg}$; the pellet was discarded. The supernatant was treated with the addition of 4 volumes of pre-chilled $10 \%$ trichloroacetic acid in acetone and incubated at $-20^{\circ} \mathrm{C}$ overnight to precipitate the 
proteins from the homogenate. The solution was then centrifuged at $4^{\circ} \mathrm{C}$ for $15 \mathrm{~min}$ at $18,000 \times \mathrm{xg}$ and the protein pellet was washed with pre-chilled acetone and centrifuged again at $4^{\circ} \mathrm{C}$. After air-drying for at least 20 minutes, the pellet was re-suspended in rehydration buffer [7M urea, 2M thiourea, 2\% cholamidopropyl-dimethylammoniopropanesulfonic acid (CHAPS), $2 \%$ nonyl phenoxylpolyethoxylethanol (NP)-40, 0.002\% Bromophenol Blue, 0.5\% IPG buffer and 100mM dithioerythritol]. 2-D Quant kit (GE Healthcare), was used to determine the protein concentration according to manufacturer's instructions.

Proteins were separated according to their isoelectric point using $11 \mathrm{~cm}$ IPG strips $\mathrm{pH}$ 47 (GE Healthcare). A $2 \mathrm{mg} / \mathrm{ml}$ dilution of each of the rehydrated protein solutions was prepared and $200 \mu \mathrm{L}$ was dispensed onto 6 replicate IPG strips in an isoelectric focusing tray (Bio-Rad). The isoelectric focusing protocol used is as follows: $5 \mathrm{~h}$ of passive rehydration, $12 \mathrm{~h}$ at $50 \mathrm{~V}, 500 \mathrm{~V}$ for $1 \mathrm{~h}, 1000 \mathrm{~V}$ for $1 \mathrm{~h}$ and $8000 \mathrm{~V}$ for $2.5 \mathrm{~h}$. Strips were then stored at $-80^{\circ} \mathrm{C}$ to await further processing.

Frozen strips were thawed and immersed in two measures of equilibration buffer [375mM Tris-base, 6M urea, 30\% glycerol, 2\% SDS (sodium dodecyl sulfate) and 0.002\% Bromophenol Blue] for $15 \mathrm{~min}$, first with 65mM dithiothreitol and then, second with $135 \mathrm{mM}$ iodoacetamide. IPG strips were affixed on a $12 \%$ polyacrylamide gel with a $0.8 \%$ agarose solution containing Laemmli SDS electrophoresis buffer as an overlay (25 mM Tris-base, $192 \mathrm{mM}$ glycine and 0.1\% SDS). Gels were run at $200 \mathrm{~V}$ for approximately 1 hour with a recirculating water bath set at $10^{\circ} \mathrm{C}$ on a Criterion Dodeca (BioRad) apparatus. Gels were subsequently stained with colloidal Coomassie Blue (G250) overnight and destained by washing with ultrapure water for $24 \mathrm{~h}$ under gentle 
agitation. The gels were imaged and saved using a flat-bed document scanner (Epson 1280).

Gel image analysis was done using the software Delta2D (version 3.6; Decodon, Greifswald, Germany) as described by Berth et al ${ }^{x i}$. The images of each of the 6 gels from each of the 4 conditions were fused together and warped so that homologous protein spots would overlap (Figure. 1). Spot boundaries were defined on this composite image and transferred back to the original gel images. Relative protein density was calculated for each spot and normalized against the total spot density of each gel.

A two-way ANOVA $(\mathrm{P}<0.01)$ was used to identify which proteins had significant changes in expression between the temperature, autoinducer, and combined condition (as an interaction). A P-value of 0.01 to limit the number of false positives as an alternative to using a multiple-comparison correction. A Tukey's analysis $(\mathrm{P}<0.05)$ was performed using MiniTab (version 17; Minitab Inc., State College, PA, USA), to validate the differences between individual protein expression profiles (Data not shown).

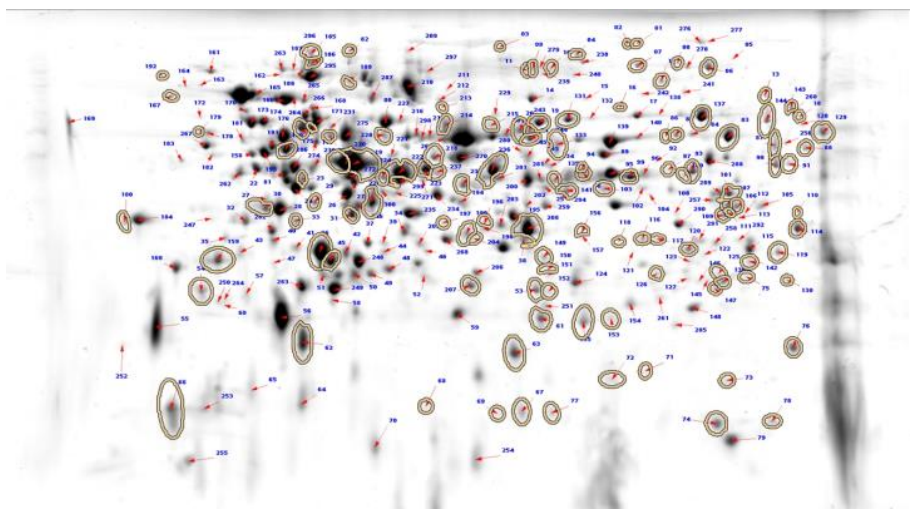

Figure 1: Composite Gel Fusion Image. A composite gel fusion image displaying the spot boundaries of 149 proteins found to have been significantly affected by an interaction between the temperature and autoinducer conditions. A total of 378 spots were enumerated. Proteins are represented by dark spots and their darkness is correlated with relative concentration. These proteins are separated by size $(20-100 \mathrm{kDa})$ on the vertical axis by Polyacrylamide Gel Electrophoresis, and by isoelectric point ( $\mathrm{pH} 4-7)$ on the horizontal axis by Isoelectric Focusing. 


\section{Protein Identification}

All 149 spots determined by two-way ANOVA to have been affected by an interaction of the temperature and autoinducer conditions were excised from the gel and destained using $25 \mathrm{mM}$ ammonium bicarbonate in 50\% acetonitrile, dehydrated with $100 \%$ acetonitrile and digested with $11 \mathrm{ng} / \mu \mathrm{l}$ trypsin (Promega, Madison, WI, USA) overnight at $37^{\circ} \mathrm{C}$. Protein was extracted from the de-stained gel plugs using a $2: 1$ solution of $0.1 \%$ trifluoroacetic acid in acetonitrile and concentrated using a SpeedVac centrifugal concentrator (Thermo Fisher Scientific, Waltham, MA, USA). The extracted protein was then solubilized in $5 \mu \mathrm{l}$ of matrix solution $(0.2 \mathrm{mg} \mathrm{ml}-1$ a-hydroxycyano cinnamic acid in acetonitrile) and spotted on an Anchorchip ${ }^{\mathrm{TM}}$ target plate (Bruker Daltonics Inc., Billerica, MA, USA). The spotted proteins were rinsed with a $0.1 \%$ TFA solution and recrystallized using an acetone/ethanol/0.1\% TFA (6:3:1) mixture.

Peptide Mass Fingerprints (PMFs) were determined using a matrix-assisted laser desorption ionization tandem time-of-flight (MALDI-TOF-TOF) mass spectrometer (Ultraflex II; Bruker Daltonics Inc.) and analyzed following a similar procedure as previously published by Tomanek and Zuzow ${ }^{\mathrm{ix}}$. Protein identification was done using Mascot (version 2.2; Matrix Science Inc., Boston, MA, USA) and combined PMFs and tandem mass spectra in a search against two databases. The first was a database associated with sequenced Aliivibrio (Wellcome Trust Sanger Institute, 2008), the other was a generic database of known prokaryotic sequences (NCBI, 2012). The molecular weight search (MOWSE) score that indicated that scores higher than 31 were significant $(P<0.05)$ for accurate identification. Only positive identifications that included two peptide matches were accepted. Based on this criterion, only 86 of the 149 protein spots analyzed by Delta 2D yielded unique, robust, identifications. 


\section{$\underline{\text { Results and Analysis }}$}

\section{Luminescence assay of lux operon gene expression}

Luminescence expression assay of $V$. salmonicida between optimal $\left(15^{\circ} \mathrm{C}\right)$ and diseasecausing $\left(5^{\circ} \mathrm{C}\right)$ temperatures shows a 30 -fold increase of relative luminescence (RLU) per cell (Figure 1) with the addition of decyl aldehyde substrate. RLU values of both cultures are similar up to an optical density $\left(\mathrm{OD}_{600}\right)$ of approximately 2.0. These data imply a link between cold temperature and density-dependent quorum sensing in $V$. salmonicida.

These assays were repeated by performing end-point confirmation experiments on cultures grown at these respective temperatures (data not shown).

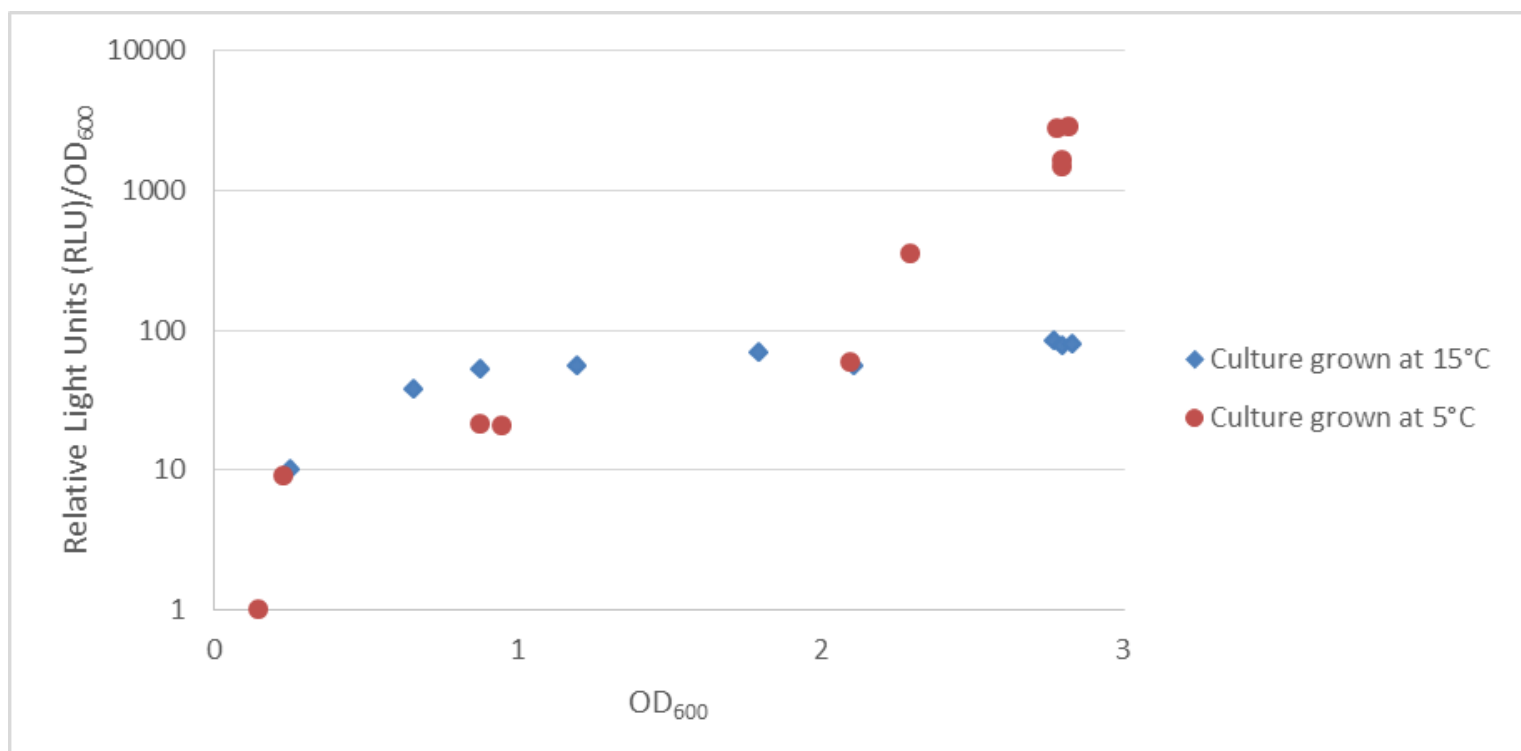

Figure 2: Temperature-Dependent Luminescence of Vibrio salmonicida at Quorum Sensing Densities. Relative specific luminescence during the growth of a broth culture of $V$. salmonicida plotted on the vertical axis using a logarithmic scale vs. the $\mathrm{OD}_{600}$ of the bacterial culture plotted on the horizontal axis. Luminescence per cell is upregulated nearly 30 -fold at high cell densities for $5^{\circ} \mathrm{C}$ compared to the $15^{\circ} \mathrm{C}$ condition. 


\section{Identified Proteins}

Using this workflow, 149 spots were identified using Delta 2D to be differentially expressed as a result of an interaction between the addition of autoinducer and temperature. After excising these spots and running an identification using MALDI, 89 yielded robust identification. A table of these identified proteins, as well as a heat map demonstrating the relative density of each protein spot within the $2 \mathrm{D}$ gel are included in Appendix I. The remainder of the results section will analyze a few of the identified proteins which have putative links to virulence, and how their expression is affected by both temperature and autoinducer.

\section{Outer Membrane Proteins}

Two outer membrane proteins (OMPs) were identified as significantly affected by temperature change and autoinducer. One hypothetical OMP (YP_002264356) displayed no significant variation in expression except at the $15^{\circ} \mathrm{C}$ with autoinducer condition where it exhibited more than double the expression of the control. Since this OMP has not been experimentally characterized, its function remains both presumptive and largely unknown. The other OMP protein was identified as OmpU (YP_002262108). The relative expression of OmpU more than doubled from the control condition to the $5^{\circ} \mathrm{C}$ condition with autoinducer. There also was a synergistic effect between $5^{\circ} \mathrm{C}$ temperature and the presence of autoinducer in inducing the expression of the protein.

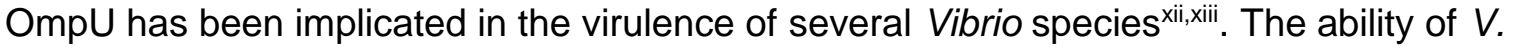
cholerae to colonize infant mice intestines reduced 100 -fold following the loss of ompU expression $^{\text {xiv }}$. This strain was also deficient in its ability to secrete toxin and inhibited in its resistance to bile salts and anionic detergents. In both in $V$. cholerae and $V$. fischeri, OmpU plays a significant role as an adhesin important to the successful colonization and 
growth within its host ${ }^{\mathrm{tv}, \mathrm{xv}}$. A strain of $V$. fischeri with a partial $o m p U$ deletion displayed a $60 \%$ reduction in its ability to colonize Euprymna scolopes. The strain also displayed reduced growth rates upon colonizing the host. Another study discovered that ompU expression led to the production or excretion of a factor that prevented phagocytosis of $V$. fischeri cells by host haemocytes, indicating that $\mathrm{OmpU}$ may play a role in the evasion of the host immune responsexvii.

The upregulation of $\mathrm{OmpU}$ in $V$. salmonicida in response to the effects of both cold temperature and autoinducer indicate that it, too, may be involved with host colonization and infection. Previous studies have shown OmpU's specific importance in the evasion of the immune mechanisms of Salmo salar. The results of one such study was presented by the author of this thesis at the ASM General Meeting in June $2015^{x / v i}$ (See appendix II). This poster presented findings that a Campbell mutation of OmpU (OmpU) showed reduced survival in the presence of fetal bovine serum, polymyxin $B$, and bovine bile compared to the wild-type strain and a complemented strain of OmpU, restoring wild-type function by re-inserting plasmid-bound ompU. Despite the positive results in these studies, further research is necessary to fully understand this protein's involvement in the virulence of $V$. salmonicida ${ }^{\text {xviii }}$.

\section{Heat/Cold Shock Proteins and Molecular Chaperones}

Six proteins identified as Heat Shock Proteins (HSP's), Cold Shock Proteins (CSP's), or Molecular Chaperones were significantly affected by the warmer temperature and the introduction of autoinducer. These proteins are largely responsible for the proper folding and stability of proteins throughout the upper range of $V$. salmoncida temperature tolerance. Of note are HSP 70, HSP 90, GrpE, FtsH, and SlyD. The other protein was an uncharacterized putative CSP. 
As expected, HSP 70 (DnaK) and HSP 90 exhibited lower expression at the colder temperature condition. While temperature was the largest contributor to the expression of these proteins, autoinducer did still have a significant upregulating effect on the expression of DnaK at the $15^{\circ} \mathrm{C}$ temperature conditions. Also identified was HSP 70 's co-chaperone, GrpE, which had a relative decrease in expression of $53 \%$ in the $5^{\circ} \mathrm{C}$ condition with autoinducer compared to the control. HSP 90 aids DnaK in the proper folding of proteins in response to heat stress. DnaK and GrpE are responsible for the refolding or degradation of denatured or mis-folded proteins, usually in response to increased heat stress. Therefore, the reduced expression of these proteins in response to the $5^{\circ} \mathrm{C}$ conditions is expected.

FtsH is a cytosolic zinc metalloprotease also characterized as a chaperone with activities important to cell division ${ }^{\mathrm{xix}}$. A primary function of this enzyme is the degradation of $\sigma^{32}$, a global heat-shock sigma factor responsible for the induction of DnaK and other heat shock proteins ${ }^{\mathrm{xx}}$. FtsH was expressed in both of the $15^{\circ} \mathrm{C}$ conditions and the $5^{\circ} \mathrm{C}$ condition with autoinducer. FtsH has significantly reduced expression in the $5^{\circ} \mathrm{C}$ condition without autoinducer. Previous work showed that $\sigma^{32}$ is rapidly degraded by FtsH so that once higher temperature stress was eliminated, expression of HSP's might be promptly terminated ${ }^{\mathrm{xxi}}$ as $\sigma^{32}$ is likewise responsible for the production of $\mathrm{FtsH}$. The co-expression of DnaK and $\mathrm{FtsH}$ in response to the $15^{\circ} \mathrm{C}$ temperature condition supports this model. See Figure 5 for a visual depiction of the $\sigma^{32}$ mediated heat shock response and the role that the enzymes identified in this study play in repairing or degrading heat denatured proteins. 


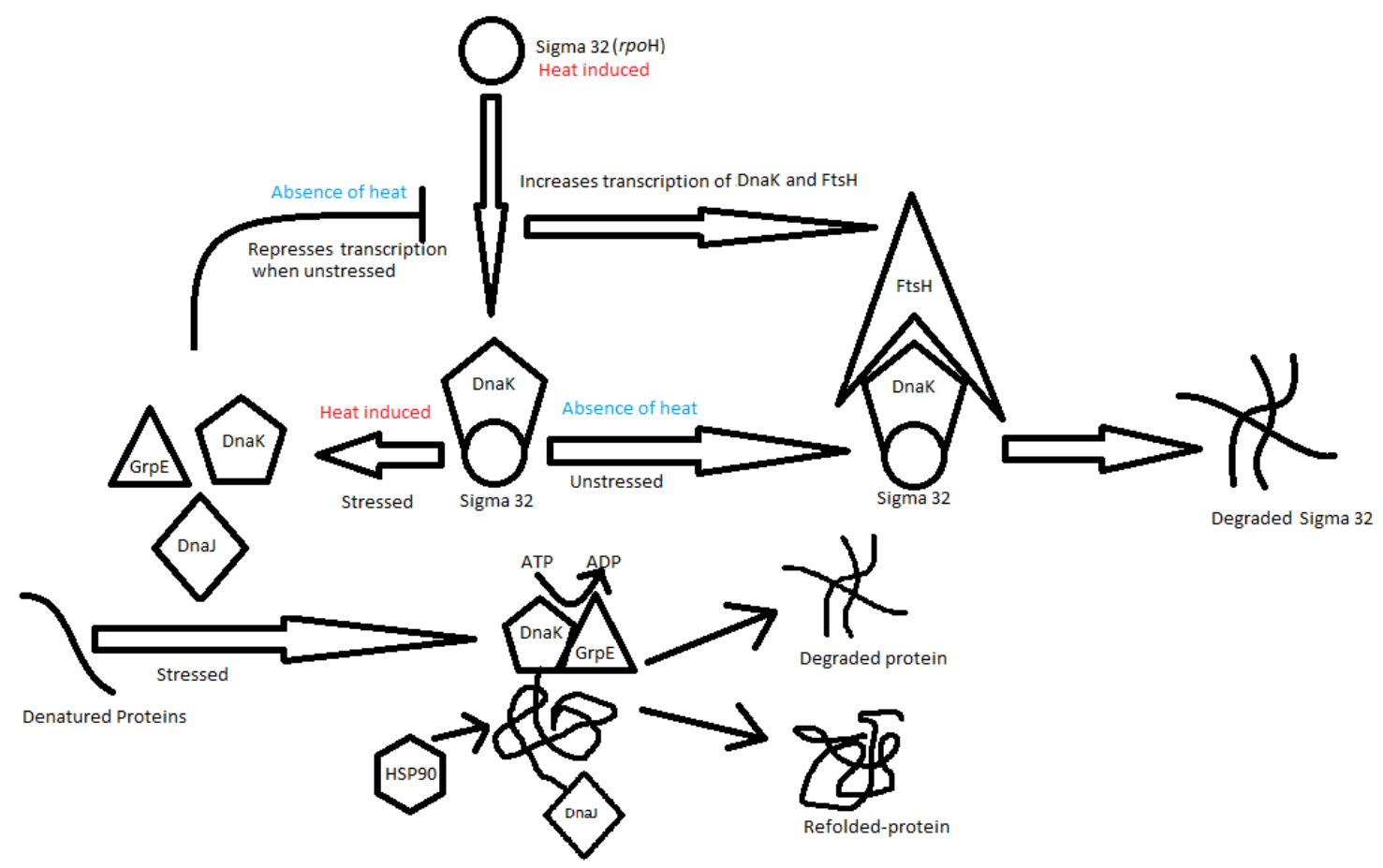

Figure 3: Regulatory pathway of heat shock proteins identified in response to temperature and autoinducer. The purpose of this pathway is to degrade or re-fold proteins that are denatured during times of heat stress. $\sigma 32$ production is induced by heat, but signaled for degradation by FtsH by DnaK when the heat stress is removed. The repression of GrpE and DnaK is indicative of the repression of $\sigma 32$ experienced in the $5^{\circ} \mathrm{C}$ (no heat stress) condition.

It is unknown why expression of $\mathrm{FtsH}$ is restored by autoinducer in the $5^{\circ} \mathrm{C}$ condition, perhaps it is due to a function of FtsH unrelated to the $\sigma^{32}$ heat-shock pathway. FtsH is also known to regulate the expression of $\mathrm{LpxC}$ and $\mathrm{KdtA}$ which are responsible for the biosynthesis of the Lipid A and Polysaccharide components of lipopolysaccharide required for cell growth and division ${ }^{4}$. Since quorum sensing increases transcription in a variety of regulons, it is possible that the increase in $\mathrm{FtsH}$ at $5^{\circ} \mathrm{C}$ is necessary to ensure that the cell does not divide too rapidly.

SlyD is a chaperone responsible for the proper folding and solubility of aggregationprone proteins; it also facilitates the insertion of a nickel co-factor for HypB, especially 


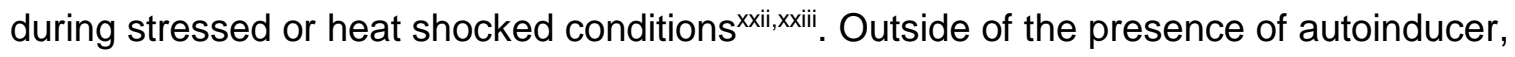
expression of SlyD was nearly identical between the temperature conditions. However, with the introduction of autoinducer, there was a temperature-dependent relative increase in the expression of SlyD in the $15^{\circ} \mathrm{C}$ condition. As temperatures approach $15^{\circ} \mathrm{C}$, roughly the upper temperature limit for $V$. salmonicida, presumably there would be increased temperature stress on bacterial enzyme function. On its own, this increased stress might not be enough to increase SlyD production. However, due to the large increase in protein synthesis that happens in the presence of autoinducer, it would be intuitive to believe that SlyD induction may be necessary to facilitate the proper folding and solubilization of aggregation-prone proteins.

\section{Flagella Control}

A flagellar regulatory enzyme, acetate kinase (AckA), had a relative increase in expression of $32 \%$ in the disease causing condition (with autoinducer at $5^{\circ} \mathrm{C}$ ) compared to the control condition. AckA expression is positively regulated in the presence of glucose $^{\text {xxiv; }}$ however, the same nutrient media (and therefore glucose levels) were used in all conditions for this study. AckA has also been described as important in the anaerobic generation of ATP ${ }^{\times x}$. However, if energy deficiency was a factor, increased expression of AckA at colder temperature conditions would not be expected due to the increased availability of oxygen for aerobic respiration. AckA has been implicated in flagellar motor regulation through the CheA independent phosphorylation of CheY, increasing the clockwise signal strength during flagellar rotation. Previous studies indicate that flagellar protein expression is likely controlled by exposure to high salinity and mucus ${ }^{i v, x x v i}$. Therefore, an increase in the levels of AckA may indicate that temperature and quorum sensing may be responsible for increasing the signal strength for flagellar rotation. However, it is also known that the phosphorylation of CheY through 
AckA is several orders of magnitude less efficient than phosphorylation through CheA, so flagellar rotational increase is unlikely to be a primary consequence of increased levels of AckAxlviii.

Studies in E. coli show that phosphorylation of OmpR by AckA led to the global control of many virulence factors. One is the suppression of the FlhDC operon, which in turn suppresses the formation of biofilm and induces the creation of flagellar proteins. The result is reduced cell division rates, increased biofilm formation, and a decrease in the production of flagellar proteins. Therefore, it would appear that increases of AckA in response to the disease causing conditions might lead to an increase in pathogenic biofilm formation. AckA phosphorylation of OmpR depends on increased concentrations of acetyl-CoA, typically as a byproduct of serine deamination or glycolysis. In this case, in the disease causing condition, L-serine dehydratase had a relative decrease in expression of $40 \%$ of the control condition, making L-serine an unlikely source of the necessary acetyl-CoA. Conversely, pyruvate kinase had a relative increase in expression of $251 \%$ of the control condition, likely driving the production of the acetylCoA necessary for OmpR phosphorylation.

\section{Proteases}

Intracellular proteases like PmbA and an ATP-dependent CLP protease were slightly repressed in the disease causing condition. However, expression of an exported serine protease was discovered to have a $329 \%$ increase in expression relative to the control condition. While metalloproteases such as the $V$. cholerae HAP are more commonly associated with virulence from Vibrio species, serine proteases have also been associated with virulence ${ }^{x \times v i i}$. Serine proteases have been implicated in virulence of $V$. parahaemolyticus, $V$. alginolyticus and $V$. vulnificus ${ }^{\text {xxviii,xxix }}$. In $V$. cholerae, inactivation of 
the HAP metalloprotease uncovered a serine protease that was associated with a hemorrhagic response in rabbit ileal loop ${ }^{\mathrm{xxx}}$.

Serine proteases increase the survival of Listeria monocytogenes in environments of intracellular stress. For example, mutants lacking a functional serine protease were unable to export listerolysin $\mathrm{O}$, which allows escape from macrophages and phagosomes $^{x\llcorner x}$. Given Vibrio salmonicida's need to infect salmon through mucous membranes, a proteolytic defense against immunological factors may complement the increased evasion from the immunological factors that OmpU provides.

\section{Protein Secretion}

A putative transmembrane export protein, a multidrug transporter-HlyD family, was identified to have a relative increase in expression of $165 \%$ of the cold condition with autoinducer when compared to the control condition. The HlyD like superfamily of secretion proteins are well studied in E. coli and V. cholerae (RtxD) for their ability to

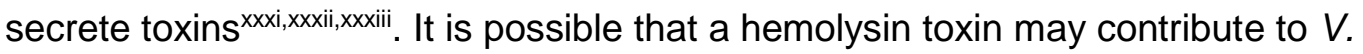
salmonicida virulence, and several hemolysin genes have been identified in the $V$. salmonicida genome ${ }^{\mathrm{xxxiv}}$. It is also likely that this transport protein is associated with the efflux of antimicrobial compounds. Indeed, the protein sequence shares significant homology with known acrivlafin resistance periplasmic proteins of Vibrio angullarum and Vibrio nigripulchritudo (80\% identity), and the Pseudomonas aeruginosa multidrug transporter membrane fusion protein MexA. V. salmonicida is known to rapidly develop resistance to antimicrobial treatment, and original antimicrobial therapies, such as tetracyclines, sulfa/trimethoprim and furazolidone are no longer considered fully effective due to resistance ${ }^{\mathrm{xxx}}$. Indeed, our recent failed attempts at generating knock-out mutants of $V$. salmonicida using a miniTn5::erm transposon has uncovered an inducible 
resistance to erythromycin, likely as a result of quorum sensing. It is possible that the induction of efflux pumps due to quorum sensing and cold temperatures may provide a means of protecting against host defense mechanisms, or may contribute to the export of a virulence factor, such as a hemolysin. For example, it has been shown in E. coli that multi-drug resistance could be induced via quorum sensing through controlling expression of efflux pumps such as $A c r A B^{\llcorner\Perp}$. Many of these efflux pumps have virulence functions in addition to multi-drug resistance. Export of bile, host immune factors, and hemolysin have also been linked to these efflux pumps ${ }^{\text {LIII. }}$

\section{N-Acyl Homoserine Lactone (HSL) production}

It is well established that Luxl expression under quorum sensing conditions induces additional Luxl expression, a feed-forward reaction that governs the production of acylhomoserine-lactone through the Luxl product acyl-homoserine-lactone synthase ${ }^{\mathrm{xxxvi}}$. It was previously unclear whether temperature variation has a significant effect on autoinducer production. It stands to reason that autoinducer production would be greater at optimal growth rates given sufficient resources.

Two enzymes that produce the two substrates for acyl-homoserine-lactone synthase were identified in this experiment ${ }^{x x x v i i}$. The first, S-adenosylmethionine synthetase, had $45 \%$ increased expression at $5^{\circ} \mathrm{C}$ with autoinducer compared to $15^{\circ} \mathrm{C}$ with autoinducer. The second enzyme, 3-ketoacyl-ACP synthase (FabB), increased relative expression by $25 \%$ at $5^{\circ} \mathrm{C}$ with autoinducer compared to $15^{\circ} \mathrm{C}$ with autoinducer.

S-adenosylmethionine synthetase produces the autoinducer precursor S-adenosyl-Lmethionine, which together with an acyl carrier protein, acyl-homoserine-lactone synthase, produces acyl-homoserine-lactone autoinducers. Experiments utilizing an 
inhibitor of FabB, cerulenin, have inhibited autoinducer production, indicating that FabB may be an important acyl carrier protein for autoinducer synthesis.

The increased expression of FabB and S-adenosylmethionine synthetase at cold temperatures with exposure to autoinducer may indicate the mechanism by which luminescence was significantly increased under cold temperatures and high cell densities in the growth curve assay.

\section{Oxidative Stress}

Iron-superoxide dismutase ([fe]SOD) and catalase (CatA) are associated with eliminating endogenous oxidative stress. Typically their levels are controlled at a relatively stable level, regardless of extracellular oxidative stress ${ }^{x x v i i i}$. Both enzymes were down-regulated at the cold temperature with autoinducer condition only. [fe]SOD decreased approximately $30 \%$ while CatA decreased approximately $15 \%$ in response to the interaction of cold and autoinducer relative to their levels in the control condition. Neither enzyme had a significant response to autoinducer activity alone, and only CatA had a marginal decrease in expression in response to cold temperature alone.

A third enzyme, thioredoxin reductase, had a $68 \%$ decrease in expression as a result of the cold temperature conditions relative to the control condition. Thioredoxin reductase is the only enzyme known to reduce thioredoxins, a class of proteins responsible for maintaining oxidative/reductive balance within the cytoplasm. Thioredoxins are capable of directly breaking down hydrogen peroxide, as well as reducing a number of disulfide bonds in numerous redox-sensitive proteins ${ }^{\mathrm{xxxix}}$.

While the response of oxidative stress to cold temperatures is not as well studied as the response to heat stress, it has been shown that oxidative stress enzymes typically increase in response to cold shock in V. vulnificus ${ }^{x \mid}$. Based on these data, it would seem 
that the response of Vibrio salmonicida to cold temperature and autoinducer is to reduce its oxidative stress response. This may be due to decreased perceived oxidative stress at lower temperatures due to lower metabolic activity. Oxidative stress is a well-known obstacle to host invasion and it seems paradoxical that $V$. salmonicida would decrease its ability to deal with oxidative stress at temperatures where it is most virulent. A previous proteomic study on $V$. salmonicida showed an increase in proteomic stress response when subjected to fish mucus ${ }^{\text {xxviii }}$. One possibility is that the expression of SOD and CatA respond independently of temperature and quorum sensing, and instead are directly responsive to the oxidative environment that the cell perceives. The data in this experiment does not support this possibility, as temperature and quorum sensing did not independently affect the expression of SOD, and only marginally affected the expression of CatA. Instead, the interaction of the two conditions $\left(5^{\circ} \mathrm{C}\right.$ temperature and autoinducer $)$ produced significant decreases in both enzymes, indicating a synergistic effect.

One study determined the activity of CatA relative to the homologous catalase from Proteus mirabilis. The study determined that CatA from $V$. salmonicida is adapted for cold-water activity. The relative activity from the enzyme from $0-10^{\circ} \mathrm{C}$ is $100 \%$, whereas the relative activity of the enzyme at $15^{\circ} \mathrm{C}$ rapidly diminishes to approximately $80 \%$ of maximum. Therefore the $14 \%$ reduction in relative enzyme abundance between the control and disease causing conditions is more than offset by a nearly $25 \%$ increase in maximum relative efficiency.

Furthermore, it has been shown that aldehyde-deficient luciferase produces a halfreaction in which $\mathrm{FMNH}_{2}$ partially reduces oxygen to hydrogen peroxide instead of the normal luminescence reaction ${ }^{x l i}$. The luminescence expression experiment earlier in this study showed that an interaction between cold temperature and autoinducer significantly 
increases the expression of luciferase. It is logical to conclude that this would also result in an increase in hydrogen peroxide producing half-reactions that the cell would have to control. One proposed possibility is that $V$. salmonicida uses oxygen radicals generated through luciferase production as a virulence factor, exporting it to cause damage to its host, however, no increased peroxide production was detected when using peroxidase assays with $V$. salmonicidaxtii. One limitation is that the previous experiments were done at room temperature with cultures not subject to autoinducer. They were also performed with a different reference strain, NCMB 2262, which was never recovered from a diseased salmon, like the LFI1238 strain, and with a less nutritious culture media, SWT. It may be useful to repeat the peroxide experiments on the LFI 1238 strain in BHI broth at $5^{\circ} \mathrm{C}$ with added autoinducer.

\section{Genomic Search for Lux Box}

The promotor region of six protein-encoding genes (Table 3) identified in this study and suspected of being linked to virulence were compared to known V. salmonicida LFI 1238 autoinducer-regulated promoter sequences in order to identify a putative "lux box." A lux box is a semi-conserved semi-palindromic promoter element, which binds to LuxR when it is bound to autoinducer ${ }^{\mathrm{IV}}$. Lux box sequences are approximately 20 nucleotides in length, located between -50nt and -100nt from the start of transcription, AT-rich, contain the nucleotide " $T$ " in the $5^{\text {th }}$ position, and contain palindromic elements, which center around a sequence of "AAGTT"IV. The strength of the promotor is related to its sequence and it's adherence to the $5^{\text {th }}$ position " $T$ " and conserved center palindromic element. The presence of a lux box is a reasonable indication of whether or not a gene is at least partially regulated by LuxR-based quorum sensing. This analysis lends further support that the proteins with aligned lux box elements displayed in Table 3 are indeed differentially expressed in response to quorum sensing. Three of the proteins had a 
promoter region (between -50nt and -100nt) containing a sequence with weak alignment to LuxR1.

\begin{tabular}{|l|l|}
\hline Putative Lux Box Sequence & Gene Annotation \\
\hline ACTCTGTAAA G TTATACAGGT & LuxR1 \\
\hline CAAGTAATAACG TTATTAGTAT & Exported Serine Protease \\
\hline AACGTAATAA G TTATCAACAA & Outer Membrane Protein OmpU \\
\hline AAAATAATAA GIAAAITITGA & Multidrug Transporter HlyD \\
\hline No Lux Box found & 3-ketoacyl-ACP synthase FabB \\
\hline No Lux Box found & Acetate Kinase AckA \\
\hline No Lux Box found & Superoxide Dismutase SodB \\
\hline
\end{tabular}

Figure 4: Detection of the lux box of Hypothetical Virulence-Related Proteins. Putative Lux Box elements displayed for four of seven proteins identified in this study and hypothesized to play a role in $V$. salmonicida virulence. Lux R1 is displayed as a known lux box for comparison. 


\section{Conclusion}

Physiological experiments show that cold temperature and addition of exogenous VAl1 autoinducer produce a significant increase in the aldehyde-supplemented per cell luminescence of $V$. salmonicida. In the course of this study, we detected 147 proteins that were differentially expressed as a result of an interaction between pathogenically relevant cold temperatures and VAl1-based quorum sensing. However, only 86 of those proteins were identifiable, leaving an incomplete picture of these interactions. Nonetheless, several new and supported hypotheses were observed as a result of this study.

This study has uncovered or supported a number of $V$. salmonicida's possible virulence mechanisms in response to quorum sensing at low temperature. Specifically, an increase in OmpU may serve to help avoid host immune response including immunological factors found in serum and anionic detergents like bile (see Appendix II). OmpU may be a valid target for further vaccine development against $V$. salmonicida. Previous studies indicate that OmpU vaccines for susceptible fish species have conferred significant resistance to $V$. alginolyticus and $V$. harveyi infection.

Increased AckA expression may not induce flagallar rotation to aid in host infection, but it may lead to a decrease in flagallar protein expression and promote biofilm formation leading to increased survival after host invasion. Excreted serine proteases and reactive oxidative species might serve to damage the host and cause the non-specific hemorrhages and internal organ damage that the host experiences upon advanced infection with $V$. salmonicida. Finally, quorum sensing and temperature-associated regulation of $\mathrm{HlyD}$ and other membrane associated efflux pumps may explain the ability 
of $V$. salmonicida to rapidly adapt to antibiotics; this may also provide a mechanism for exporting hemolysin or other biological toxins. Several putative hemolysins have been annotated in the $V$. salmonicida genome, but none have yet been experimentally shown to be expressed $x \times x v 1$.

This study identified a putative lux box for OmpU, exported serine protease, and HlyD. This strengthens support for the effect of quorum sensing on the expression of these proteins and their role in virulence. The absence of a lux box does not preclude a gene's regulation by quorum sensing. Luxl may bind to parts of the promoter element yet to be described as a lux box, or the gene may be expressed secondarily by quorum sensing through another transcription factor. Future studies utilizing these promoter elements in a plasmid-reporting expression assay can experimentally demonstrate that these putative lux boxes are functional, and even go as far as to show the degree to which they regulate expression of their downstream genes.

One limitation of the study presented in this thesis is the use of a single autoinducer, VAl1, to emulate a communal interaction of a culture of $V$. salmonicida. This might limit our ability to detect other important physiological functions that may have an effect on the virulence of the organism. For example, V. salmonicida produces another autoinducer (i.e.hexanoyl homoserine lactone), that might play a synergistic or antagonistic role with VAl1 and virulence ${ }^{\mathrm{L}}$.

For the future, knockout and complementation studies should show the functional role that HlyD has in antibiotic resistance and the role that exported serine protease may play in virulence. Furthermore, development of phenotypic screens to reveal the in vitro deficiencies of these mutants will aid in characterizing gene function. It has recently been hypothesized that host secretions such as mucin and other immunological factors 
are necessary for the expression of certain virulence mechanisms in $V$. salmonicida ${ }^{\text {xilii }}$. Another proteomic study merging the cold temperature and autoinducer conditions of this study, and the hypothetically necessary host factors might reveal a clearer picture of $V$. salmonicida pathogenesis. For example, it might serve to elucidate the role of the oxidative stress response in virulence. Physiological studies of putative virulence factors in $V$. salmonidica must be done in conditions that emulate the host during infection. One such collaborative study between the Fidopiastis and Bjelland Labs is utilizing dialysis tubing with culture media to grow $V$. salmonicida inside Salmo salar hosts. This tubing can be collected and this experiment repeated to see how the expression of the soluble proteome changes in response to various host factors.

While the results of this study may not paint a complete picture of $V$. salmonicida virulence, it has produced many hypotheses for future research to test. Also, future hypothesis-driven studies, whether they use in vivo salmon infection techniques or use individual host factors such as mucin in vitro, combined with the understanding that temperature and quorum sensing are integral to the virulence of $V$. salmonicida, should reveal the mechanisms that the organism utilizes to invade, infect and subsist in its hosts. 


\section{REFERENCES}

I. Egidius, Wiik, Andersen, Hoff and Hjeltnes, "Vibrio salmonicida sp. nov., a New Fish Pathogen," IJSEM, October 1986, vol. 36 no. 4 p518-520

II. Nordmo, Holth, Riseth, Varma, Sutherland and Brokken, "Evaluation of florfenicol in Atlantic salmon, Salmo salar L.: efficacy against furunculosis due to Aeromonas salmonicida and cold water vibriosis due to Vibrio salmonicida," Journal of Fish Diseases, July 1998, Volume 21, Issue 4, p289-297

III. Johansen "Fiskehelserapporten 2012" Oslo: Veterinærinstituttet, Accessed 04/03/2016. http://www.vetinst.no/Publikasjoner/Fiskehelserapporten/Fiskehelserapporten-2012

IV. Nelson, Tunsjø, Fidopiastis, Sørum and Ruby, "A Novel lux Operon in the Cryptically Bioluminescent Fish Pathogen Vibrio salmonicida Is Associated with Virulence," Appl. Environ. Microbiol., March 2007, vol. 73 no. 6 p1825-1833

V. Hjelmeland, Stensvaag, Jørgensen and Espelid, "Isolation and characterization of a surface layer antigen from Vibrio salmonicida" J. Fish Dis., 1988, 11, p197-205

VI. Karlsen, Paulsen, Tunsjø, Krinner, Sørum, Haugen and Willassen, "Motility and flagellin gene expression in the fish pathogen Vibrio salmonicida: Effects of salinity and temperature" Microbial Pathogenesis, October 2008, Volume 45, Issue 4, p258-264

VII. Colquhoun and Sørum, "Temperature dependent siderophore production in Vibrio salmonicida," Microbial Pathogenesis, November 2001, Volume 31, Issue 5, p213-219

VIII. Egland and Greenberg, "Quorum sensing in Vibrio fischeri: elements of the luxI promoter," Molecular Microbiology, February 1999, Vol. 31, Issue 4, p1197-1204

IX. Zhu, Miller, Vance, Dziejman, Bassler, and Mekalanos, "Quorum-sensing regulators control virulence gene expression in Vibrio cholerae," PNAS, March 5, 2002 vol. 99 no. 5

X. Tomanek and Zuzow, "The proteomic response of the mussel congeners Mytilus galloprovincialis and $M$. trossulus to acute heat stress: implications for thermal tolerance limits and metabolic costs of thermal stress," J Exp Biol 213, p3559-3574

XI. Berth, Moser, Kolbe and Bernhardt, "The state of the art in the analysis of twodimensional gel electrophoresis images." Applied Microbiology and Biotechnology, October 2007, Volume 76, Issue 6, p1223-1243

XII. Chakrabarti, Chaudhuri, Sen, and Das, "Porins of Vibrio cholerae: purification and characterization of OmpU," J. Bacteriol. January 1996 178:2 p524-30

XIII. Goo, Lee, Kim, Han, Park, Lee, Kim, Kim, Lee and Park, "Identification of OmpU of Vibrio vulnificus as a Fibronectin-Binding Protein and Its Role in Bacterial Pathogenesis," Infect. Immun. October 2006, vol. 74 no. 10 p5586-5594

XIV. Provenzano and Klose, "Altered expression of the ToxR-regulated porins OmpU and OmpT diminishes Vibrio cholerae bile resistance, virulence factor expression, and intestinal colonization," PNAS 200097 (18) p10220-10224 
XV. Sperandio, Girón, Silveira and Kaper, "The OmpU outer membrane protein, a potential adherence factor of Vibrio cholerae," Infect. Immun. November 1995, vol. 63 no. 11 p4433-4438

XVI. Aeckersberg, Lupp, Feliciano, and Ruby, "Vibrio fischeri Outer Membrane Protein OmpU Plays a Role in Normal Symbiotic Colonization," J. Bacteriol. November 2001, vol. 183 no. 22 p6590-6597

XVII. Nyholm, Stewart, Ruby and McFall-Ngai, "Recognition between symbiotic Vibrio fischeri and the haemocytes of Euprymna scolopes" Journal of Environmental Microbiology, October 2008, 11, p1462-2920

XVIII. Bjelland, "Adaptation and virulence in Vibrio salmonicida," Doctoral Thesis, Dec. 1, 2011, Norweigen School of Vetrinary Science - Oslo, Norway

XIX. Cai, Yaol, Lu, Wu, Jian and Wang, "Immune response in Lutjanus erythropterus induced by the major outer membrane protein $(\mathrm{OmpU})$ of Vibrio alginolyticus."Diseases of Aquatic Organisms, 2010, 90(1) p63-68

XX. Wang, Chen, Liu and Jia, "Identification and evaluation of an outer membrane protein OmpU from a pathogenic Vibrio harveyi isolate as vaccine candidate in turbot (Scophthalmus maximus)" Letters in Applied Microbiology, May 2011

XXI. Schumann, "FtsH--a single-chain charonin?" FEMS Microbiol Rev., 1999 Jan;23, p1-11.

XXII. Grossman, Straus, Walter and Gross, "Sigma 32 synthesis can regulate the synthesis of heat shock proteins in Escherichia coli" Genes Dev., 1987, p179-184

XXIII. Gamer, Multhaup, Tomoyasu, McCarty, Rudiger, Schonfeld, Schirra, Bujard and Bukau, "A cycle of binding and release of the DnaK, DnaJ and GrpE chaperones regulates activity of the Escherichia coli heat shock transcription factor sigma32." EMBO J., 1996, 15 p $607-617$

XXIV. Han, Song, Ahn, Park, Seo and Lee, "Solubilization of aggregation-prone heterologous proteins by covalent fusion of stress-responsive Escherichia coli protein, SlyD," Protein Eng Des Sel. 2007 Nov;20(11) p543-9

XXV. Kaluarachchi, Zhang and Zamble, "Escherichia coli SlyD, more than a Ni(II) reservoir," Biochemistry. 2011 Dec 20;50(50), p10761-3

XXVI. Grundy, Waters, Allen and Henkjni, "Regulation of the Bacillus subtilis acetate kinase gene by CcpA" Journal of Bacteriology, Nov. 1993, p7348-7355

XXVII. Thauer, Jungermann and Decker, "Energy Conservation in Chemotrophic Anaerobic Bacteria" Bacteriological Reviews, Mar. 1977, Vol. 41, No. 1, p. 100-180

XXVIII. Ræder, Paulsen, Smalås, Willassen, "Effect of fish skin mucus on the soluble proteome of Vibrio salmonicida analyzed by 2-D gel electrophoresis and tandem mass spectrometry" Microbial Pathogenesis, Volume 42, Issue 1, January 2007, p36-45

XXIX. Aguirre-Guzmán, Ruíz and Ascencio, "A review of extracellular virulence product of Vibrio species important in diseases of cultivated shrimp, "Aquaculture Research, December 2004, Volume 35, Issue 15, p1395-1404 
XXX. Wang, Sasaki, Maehara, Nakao, Tsuchiya and Miyoshi, "Variation of extracellular proteases produced by Vibrio vulnificus clinical isolates: Genetic diversity of the metalloprotease gene (vvp), and serine protease secretion by vvp-negative strains," Microbial Pathogenesis, June 2008, Volume 44, Issue 6, p494-500

XXXI. Lee, Cheng, Yu and Pan, "Purification and characterization of a putative virulence factor, serine protease, from Vibrio parahaemolyticus," FEMS Microbiology Letters, March 2002, Volume 209, Issue 1, p31-37

XXXII. Syngkon, Elluri, Koley, Rompikuntal, Saha, Chakrabarti, Bhadra, Wai and Pal, "Studies on a Novel Serine Protease of a $\Delta$ hapA $\Delta$ prtV Vibrio cholerae O1 Strain and Its Role in Hemorrhagic Response in the Rabbit Ileal Loop Model," PLoS ONE 5(9)

XXXIII. Lin, Fullner, Clayton, Sexton, Rogers, Calia, Calderwood, Fraser, and Mekalanos, "Identification of a Vibrio cholerae RTX toxin gene cluster that is tightly linked to the cholera toxin prophage," PNAS, February 2 1999, vol. 96 no. 3, p1071-1076

XXXIV. Boardman and Fullner Satchell, "Vibrio cholerae Strains with Mutations in an Atypical Type I Secretion System Accumulate RTX Toxin Intracellularly," Journal of Bacteriology, Dec. 2004, p8137-8143

XXXV. Pimenta, Racher, Jamieson, Blight, and Holland, "Mutations in HlyD, Part of the Type 1 Translocator for Hemolysin Secretion, Affect the Folding of the Secreted Toxin," J. Bacteriol., November 2005, vol. 187 no. 21, p7471-7480

XXXVI. Hjerde, Lorentzen, Holden, Seeger, Paulsen, Bason, Churcher, Harris, Norbertczak, Quail, Sanders, Thurston, Parkhill, Willassen, and Thomson, "The genome sequence of the fish pathogen Aliivibrio salmonicida strain LFI1238 shows extensive evidence of gene decay," BMC Genomics 2008, 9, p616

XXXVII. Haug and Press, "Facts: cold water vibriosis in Atlantic salmon," Oslo: Veterinærinstituttet Updated Jan 2014. http://www.vetinst.no/Faktabank/Kaldtvannsvibriose

XXXVIII. Schaefer, Val, Hanzelka, Cronan, and Greenberg, "Generation of cell-to-cell signals in quorum sensing: acyl homoserine lactone synthase activity of a purified Vibrio fischeri Luxl protein". Proc. Natl. Acad. Sci. USA 93 (18), p9505-9509

XXXIX. Hanzelka and Greenberg, "Quorum sensing in Vibrio fischeri: evidence that Sadenosylmethionine is the amino acid substrate for autoinducer synthesis." J. Bacteriol., September 1996, vol. 178 no. 17, p5291-5294

XL. Vattanaviboon, Panmanee and Mongkolsuk, "Induction of peroxide and superoxide protective enzymes and physiological cross-protection against peroxide killing by a superoxide generator in Vibrio harveyi," FEMS Microbiology Letters 221, 2003, p89-95

XLI. Zeller and Klug, "Thioredoxins in bacteria: functions in oxidative stress response and regulation of thioredoxin genes," Naturwissenschaften June 2006, Volume 93, Issue 6, p259-266

XLII. Limthammahisorn, Brady, Arias, "Gene Expression of Cold Shock and Other StressRelated Genes in Vibrio vulnificus Grown in Pure Culture under Shellstock Temperature Control Conditions," Journal of Food Protection, Number 1, January 2008, p4-230 
XLIII. Gonzalez-Flecha and Demple, "Intracellular Generation of Superoxide as a By-Product of Vibrio harveyi Luciferase Expressed in Escherichia coli," Journal of Bacteriology, Apr. 1994, p2293-2299

XLIV. Bjelland, Fauske, Nguyen, Orlien, Østgaard, and Sørum, "Expression of Vibrio salmonicida virulence genes and immune response parameters in experimentally challenged Atlantic salmon (Salmo salar L.)," Front Microbiol. 2013; 4, p401.

XLV. Bjelland, Sørum, Tegegne, Winther-Larsen, Willassen and Hansen, "LitR of Vibrio salmonicida is a salinity-sensitive quorum-sensing regulator of phenotypes involved in host interactions and virulence" Infect Immun. 2012 May;80(5), p1681-9.

XLVI. Massey, Bjelland, Sørum and Fidopiastis, "A Proteomic Approach to Understanding Virulence in Vibrio salmonicida," Poster, ASM General Meeting in Boston, June 2015

XLVII. Lynnes, Prüß, and Samanta, "Acetate metabolism and Escherichia coli biofilm: new approaches to an old problem," FEMS Microbiology Letters, July 2013, p95-103

XLVIII. Wolfe, “The Acetate Switch," Microbiol. Mol. Biol. Rev., March 2005, vol. 69 no. 1 p12-50

XLIX. Gaillot, Pellegrini, Bregenholt, Nair and Berche "The ClpP serine protease is essential for the intracellular parasitism and virulence of Listeria monocytogenes," Molecular Microbiology, March 2000, Volume 35, Issue 6, p1286-1294

L. Bruhn, Dalsgaard, Nielsen, Buchholtz, Larsen and Gram L. "Quorum sensing signal molecules (acylated homoserine lactones) in gram-negative fish pathogenic bacteria," Dis Aquat Organ. 2005 Jun, 14;65(1), p43-52.

LI. Katz and Ron, "Dual Role of FtsH in Regulating Lipopolysaccharide Biosynthesis in Escherichia coli," J Bacteriol. 2008 Nov; 190(21): p7117-7122

LII. Rahmati, Yang, Davidson, and Zechiedrich, "Control of the AcrAB multidrug efflux pump by quorum-sensing regulator SdiA," Molecular Microbiology, Volume 43, Issue 3, February 2002, p677-685

LIII. Piddock, "Multidrug-resistance efflux pumps? not just for resistance," Nature Reviews Microbiology, Aug. 2006, 4, p629-636 


\section{APPENDICES}

\section{Appendix I - Table of Identified Proteins and Fusion Image and Heat Map}

The following table lists all 86 proteins that were identified from the 147 gel spots which were determined to be significantly differentially expressed using Delta 2D. Listed is the name of the protein, a classification of the putative function of protein, and the percent of relative expression of the protein in the test condition $\left(5^{\circ} \mathrm{C}\right.$ with autoinducer) compared to the control condition $\left(15^{\circ} \mathrm{C}\right.$ without autoinducer). Following this table is an expanded image of Figure 2 as well as a graphical representation of the expression of each protein (Heat Map). The Gel Spot ID numbers in this table correspond with the numbers annotated on the fusion image and Heat Map. The columns on the Heat Map represent the gel spots (likely corresponding to individual proteins) of the 6 individual replicate gels

run for each of the four conditions tested $\left(5^{\circ} \mathrm{C}+\mathrm{Al}, 5^{\circ} \mathrm{C}-\mathrm{Al}, 15^{\circ}+\mathrm{Al}, 15^{\circ} \mathrm{C}-\mathrm{Al}\right)$ where a statistically significant interaction effect was determined by Delta 2D. The rows represent individual spots on the gel fusion image, corresponding to the Gel Spot ID number. The colors represent individual expression of each gel spot as either greater than the average intensity of the spot on all the combined gels (Orange), or less than the average intensity of the spot on all the combined gels (Blue). Black denotes a gel spot that is similar in intensity to the average of that spot across all the gels. The protein spots from the heat map are grouped together by similar expression profiles. 
Table of Identified Proteins

\begin{tabular}{|c|c|c|c|}
\hline Number & Name & Putative Function & $\begin{array}{l}\% \text { Change in } \\
\text { Relative } \\
\text { Expression }\end{array}$ \\
\hline 106 & Threonine Aldolase & AA Digestion & $119 \%$ \\
\hline 101 & Chorismate Synthase & AA Synthesis & $16 \%$ \\
\hline 232 & Sulfate adenylyltransferase subunit 1 & AA Synthesis & $328 \%$ \\
\hline 214 & Glutamate decarboxylase & AA Synthesis & $137 \%$ \\
\hline 259 & $\begin{array}{l}\text { Phospho-2-dehydro-3-deoxyheptonate } \\
\text { aldolase }\end{array}$ & AA Synthesis & $134 \%$ \\
\hline 196 & Cysteine Synthase A & AA synthesis & $68 \%$ \\
\hline 274 & Argininosuccinate synthase & AA synthesis & $48 \%$ \\
\hline 223 & $\begin{array}{l}\text { N-succinyldiaminopimelate- } \\
\text { aminotransferase/acetylornithine } \\
\text { transamine protein }\end{array}$ & AA Synthesis & $32 \%$ \\
\hline 281 & Tryptophan synthase & AA Synthesis & $23 \%$ \\
\hline 270 & Serine hydroxymethyltransferase & AA Synthesis & $17 \%$ \\
\hline 177 & Glutamate Synthetase & AA Synthesis & $16 \%$ \\
\hline 208 & Cystine Synthase A & AA Synthesis & $-19 \%$ \\
\hline 190 & Threonine synthase & AA synthesis & $-40 \%$ \\
\hline 98 & Carbamoyl-phosphate synthase & AA Synthesis & $-46 \%$ \\
\hline 4 & Chorismate Synthase A & AA Synthesis & $-59 \%$ \\
\hline 75 & Glutamate Synthetase & AA Synthesis & $-65 \%$ \\
\hline 36 & Thioredoxin reductase & AA Synthesis & $-68 \%$ \\
\hline 135 & $\begin{array}{l}\text { Capsular polysaccharide biosynthesis } \\
\text { protein }\end{array}$ & Biofilm Formation & $-19 \%$ \\
\hline 301 & $\begin{array}{l}\text { Bifunctional N-acetylglucosamine-1- } \\
\text { phosphate uridyltransferase/glucosamine- } \\
\text { 1-phosphate acetyltransferase }\end{array}$ & Cell Wall Synthesis & $60 \%$ \\
\hline 228 & UDP-N-acetylmuramate--L-alanine ligase & Cell Wall Synthesis & $57 \%$ \\
\hline 159 & $\begin{array}{l}\text { FKBP-type peptidyl-prolyl cis-trans } \\
\text { isomerase SlyD }\end{array}$ & Chaperone & $-27 \%$ \\
\hline 299 & S-adenosylmethionine synthetase & DNA Methylation & $14 \%$ \\
\hline 242 & DNA topoisomerase IV subunit B & DNA Replication & $112 \%$ \\
\hline 3 & DNA Gyrase & DNA Replication & $-48 \%$ \\
\hline 142 & Formyltetrahydrofolate deformylase & DNA Synthesis & $53 \%$ \\
\hline 204 & $\begin{array}{l}\text { UTP-glucose-1-phosphate } \\
\text { uridylyltransferase }\end{array}$ & Glycogenesis & $-64 \%$ \\
\hline 20 & Pyruvate kinase $\mathrm{F}$ & Glycolysis Enzyme & $254 \%$ \\
\hline 226 & $\begin{array}{l}\begin{array}{l}\text { Glyceraldehydes-3-phosphate } \\
\text { dehydrogenase }\end{array} \\
\end{array}$ & Glycolysis Enzyme & $61 \%$ \\
\hline 19 & Pyruvate Kinase A & Glycolysis Enzyme & $61 \%$ \\
\hline 224 & Acetate Kinase & Glycolysis Enzyme & $32 \%$ \\
\hline
\end{tabular}




\begin{tabular}{|c|c|c|c|}
\hline 31 & Fructose 1,6 bisphosphotase & Glycolysis Enzyme & $11 \%$ \\
\hline 290 & 6-phosphofructokinase & Glycolysis Enzyme & $0 \%$ \\
\hline 219 & Enolase & Glycolysis Enzyme & $-17 \%$ \\
\hline 283 & Triosephosphate isomerase & Glycolysis Enzyme & $-17 \%$ \\
\hline 30 & Fructose-bisphosphate aldolase & Glycolysis Enzyme & $-26 \%$ \\
\hline 167 & Molecular chaperone DnaK (HSP70) & HSP/CSP & $-8 \%$ \\
\hline 250 & Protein GrpE & $\mathrm{HSP} / \mathrm{CSP}$ & $-53 \%$ \\
\hline 69 & Cold Shock Protein & HSP/CSP & $-85 \%$ \\
\hline 187 & HSP 90 & $\mathrm{HSP} / \mathrm{CSP}$ & $-90 \%$ \\
\hline 155 & 3-ketoacyl-ACP reductase & Lipid Synthesis & $521 \%$ \\
\hline 222 & 3-ketoacyl-ACP synthase FabB & Lipid Synthesis & $25 \%$ \\
\hline 268 & $\begin{array}{l}\text { Acetyl-CoA carboxylase } \\
\text { carboxyltransferase }\end{array}$ & Lipid Synthesis & $22 \%$ \\
\hline 288 & 3-oxoacyl-(acyl carrier protein) synthase II & Lipid Synthesis & $-7 \%$ \\
\hline 120 & UDP-N-acetylglucosamine acyltransferase & Lipid Synthesis & $-12 \%$ \\
\hline 285 & Phosphoheptose isomerase & $\begin{array}{l}\text { Lipopolysaccharide } \\
\text { Biosynthesis }\end{array}$ & $13 \%$ \\
\hline 282 & $\begin{array}{l}\text { ADP-L-glycero-D-manno-heptose-6- } \\
\text { epimerase }\end{array}$ & $\begin{array}{l}\text { Lipopolysaccharide } \\
\text { Biosynthesis }\end{array}$ & $2 \%$ \\
\hline 141 & Multidrug transporter HlyD family & Membrane transport & $166 \%$ \\
\hline 150 & $\begin{array}{l}\text { Arginine-ornithine periplasmic binding } \\
\text { protein }\end{array}$ & Membrane transport & $73 \%$ \\
\hline 292 & L-amino acid binding protein & Membrane Transport & $73 \%$ \\
\hline 45 & Methionine transporter & Membrane transport & $-24 \%$ \\
\hline 238 & 2-oxoglutarate dehydrogenase & Metabolism & $1585 \%$ \\
\hline 269 & Dihydrolipoamide dehydrogenase & Metabolism & $116 \%$ \\
\hline 244 & Dihydrolipoamide succinyltransferase & Metabolism & $39 \%$ \\
\hline 236 & Alanine dehydrogenase & Metabolism & $28 \%$ \\
\hline 280 & L-serine dehydratase & Metabolism & $-40 \%$ \\
\hline 291 & ZnuA Precursor & Metal Use & $2 \%$ \\
\hline 294 & Dihydroorotase & $\begin{array}{l}\text { Nucleic Acid } \\
\text { Synthesis }\end{array}$ & $22 \%$ \\
\hline 218 & $\begin{array}{l}\mathrm{Na}(+) \text {-translocating } \mathrm{NADH} \text {-quinone } \\
\text { reductase subunit A }\end{array}$ & Osmotic Stress & $40 \%$ \\
\hline 278 & $\begin{array}{l}\text { Bifunctional acetaldehyde-CoA/alcohol } \\
\text { dehydrogenase }\end{array}$ & Oxidative Stress & $42 \%$ \\
\hline 139 & Cat A Gene Product & Oxidative Stress & $-14 \%$ \\
\hline 62 & Superoxide dismutase & Oxidative Stress & $-29 \%$ \\
\hline 184 & OmpU & Porin & $105 \%$ \\
\hline 67 & Outer Membrane Protein & Porin & $50 \%$ \\
\hline 88 & Exported Serine Protease & Protease & $329 \%$ \\
\hline 296 & Zn dependant peptidase & Protease & $15 \%$ \\
\hline 189 & Cell division protein FtsH & Protease & $9 \%$ \\
\hline 298 & Peptidase PmbA & Protease & $-12 \%$ \\
\hline
\end{tabular}




\begin{tabular}{|c|c|c|c|}
\hline 63 & CLP Protease & Protease & $-20 \%$ \\
\hline 220 & Elongation Factor Tu & Protein Synthesis & $81 \%$ \\
\hline 263 & Phenylalanyl-tRNA synthetase subunit beta & Protein Synthesis & $70 \%$ \\
\hline 295 & Elongation Factor $\mathrm{G}$ & Protein Synthesis & $-11 \%$ \\
\hline 107 & Tryptophanyl-tRNA synthetase & Protein Synthesis & $-43 \%$ \\
\hline 83 & $\begin{array}{l}\text { Inosine-5'-monophosphate dehydrogenase } \\
\text { (IMDPH) }\end{array}$ & Protein Synthesis & $-59 \%$ \\
\hline 213 & Glutaminyl-tRNA synthetase & Protein Synthesis & $-74 \%$ \\
\hline 117 & tRNA pseudouridine synthase B & Protein Synthesis & $-81 \%$ \\
\hline 78 & Ribosomal Binding Factor A & Protein Synthesis & $-88 \%$ \\
\hline 143 & Sulfite reductase subunit beta & Sulfur use & $95 \%$ \\
\hline 97 & Cysteine desulfurase & Sulfur use & $40 \%$ \\
\hline 186 & $\begin{array}{l}\text { Bifunctional aconitate hydratase 22- } \\
\text { methylisocitrate dehydratase }\end{array}$ & TCA Cycle & $-23 \%$ \\
\hline 276 & $\begin{array}{l}\text { DNA-directed RNA polymerase subunit } \\
\text { beta' }\end{array}$ & Transcription & $332 \%$ \\
\hline 71 & Hypothetical protein VSAL_10500 & & $83 \%$ \\
\hline 197 & Hypothetical protein VSAL_I2450 & & $59 \%$ \\
\hline 86 & Calcineurin-like phosphoesterase & & $5 \%$ \\
\hline 300 & Putative Aminotransferase & & $0 \%$ \\
\hline 207 & Hypothetical protein VSAL_I1766 & & $-24 \%$ \\
\hline 125 & Putative Hydrolase & & $-60 \%$ \\
\hline
\end{tabular}


Gel Fusion Image

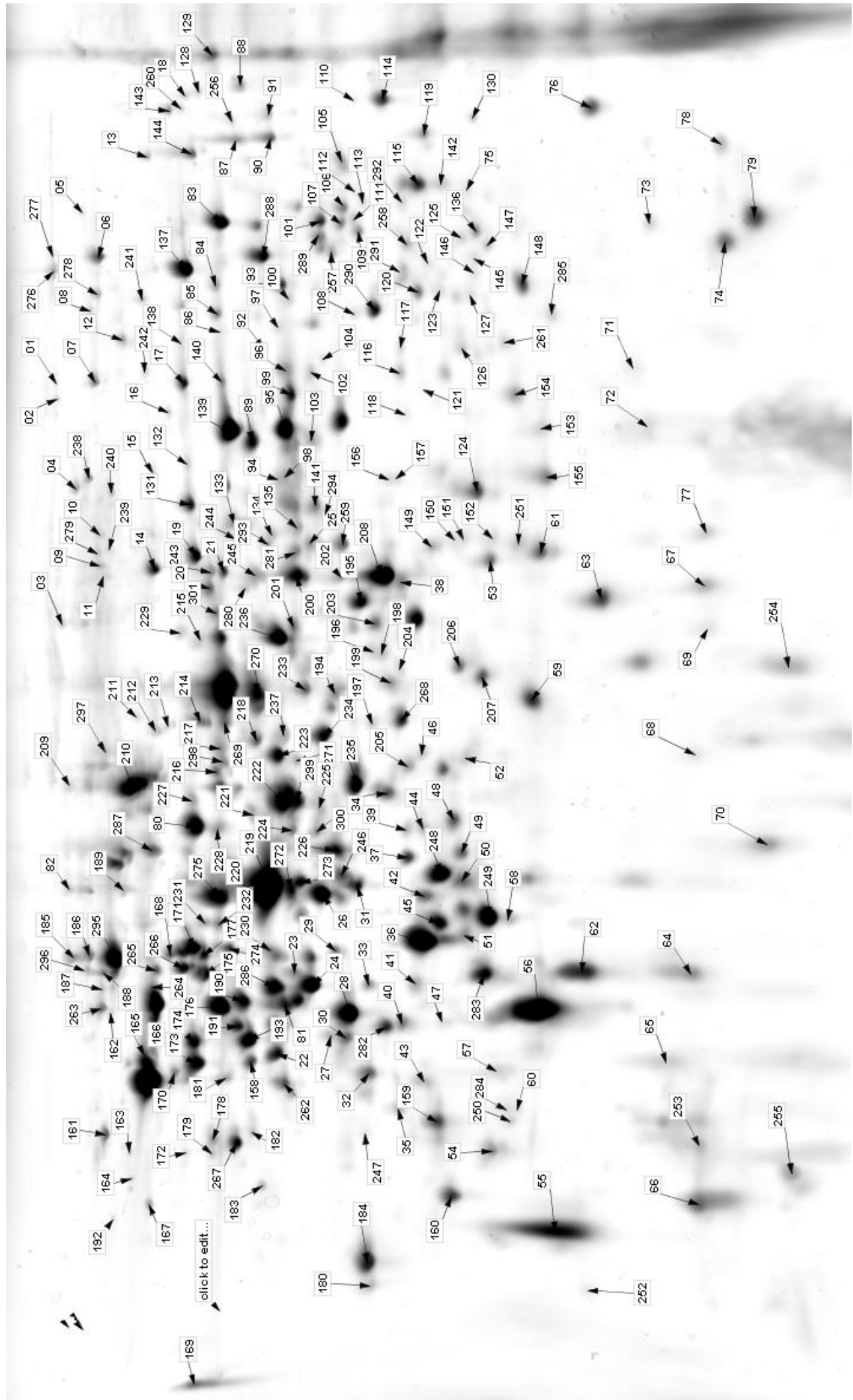




\section{Heat Map}

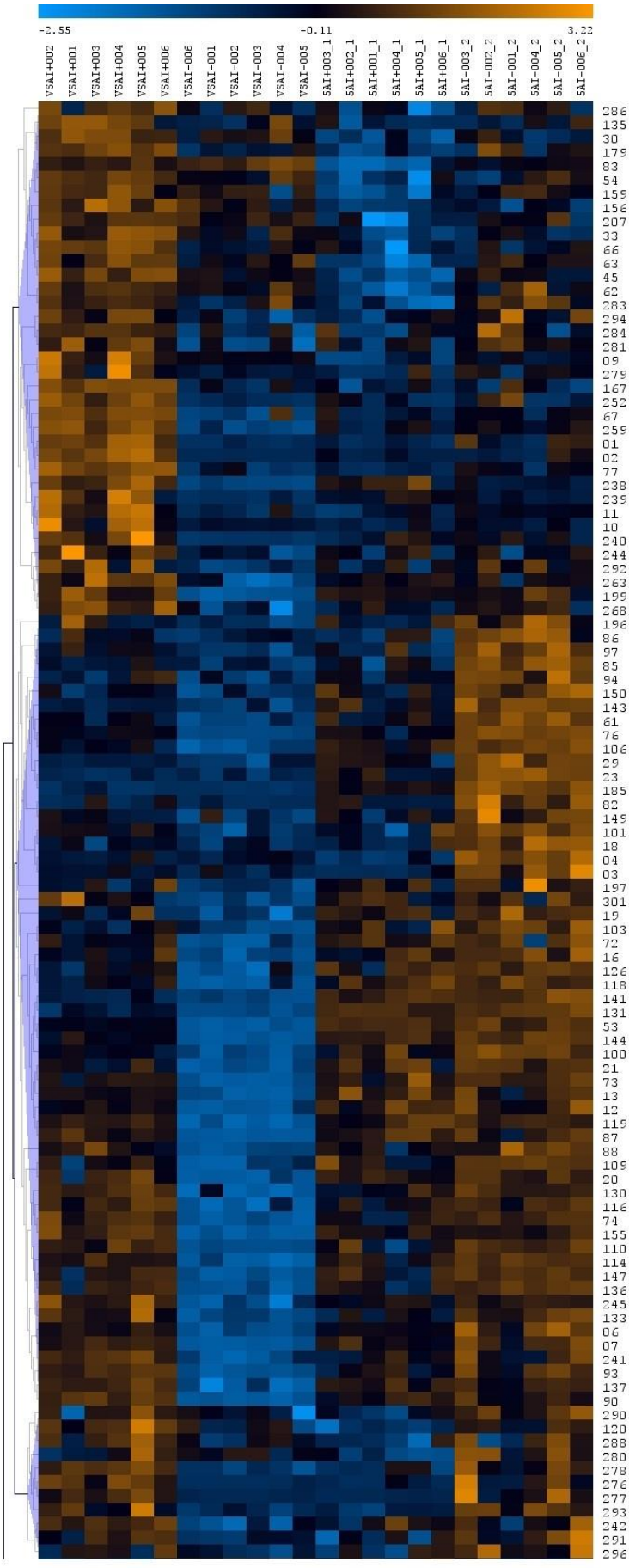

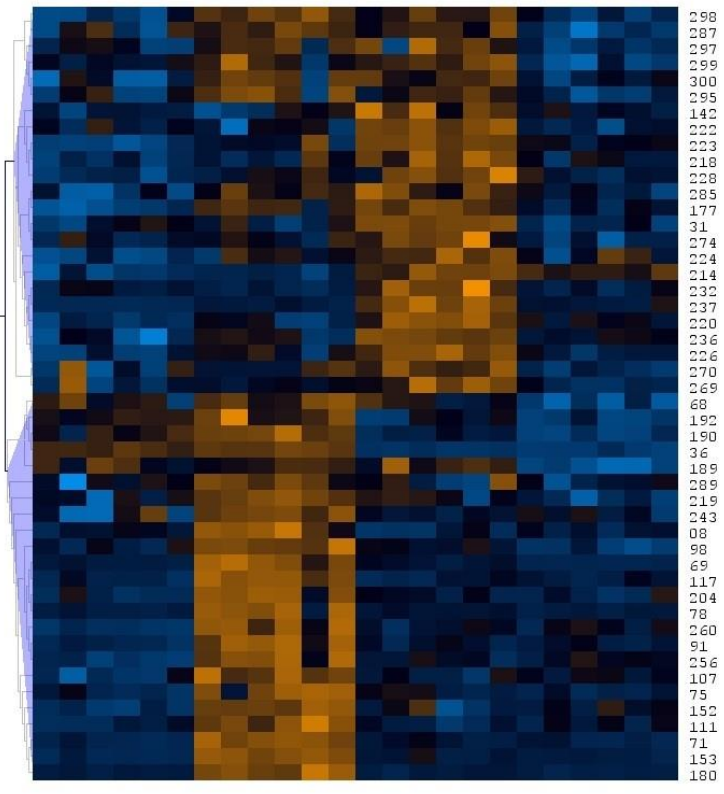




\section{Appendix II - Related Publication - Poster, ASM General Meeting, June 2015}

A proteomic approach to understanding virulence in Vibrio salmonicida Chris Massey ${ }^{1}$; Ane Mohn Bjelland ${ }^{2} ;$ Henning Sørum²; Pat M. Fidopiastis ${ }^{1}$

${ }^{1}$ Cal Poly State University, San Luis Obispo, CA ${ }^{2}$ Norwegian School of Veterinary

$$
\text { Science, Oslo, Norway }
$$

Cold water vibriosis in Atlantic salmon was characterized over 30 years ago, but surprisingly little is known about the virulence mechanisms of its causative agent, Vibrio salmonicida. However, a recent reoccurrence of outbreaks in Norwegian fisheries provided incentive to better understand the virulence mechanisms of $V$. salmonicida. Here, we used a proteomic approach to identify proteins that were differentially expressed when cells were grown in vitro under simulated virulence conditions (i.e. $8^{\circ} \mathrm{C}$ and in the presence of exogenously supplied autoinducer 3-oxo-hexanoyl-homoserine lactone). Some examples of proteins with significantly altered expression that stood out at as homologs of potential virulence factors were: a serine protease (DegQ, VSAL_I2667), a multi-drug transporter (HlyD, VSAL_10090), and an outer membrane protein (OmpU, VSAL_10588). In support of our proteomics findings, cells of an ompUstrain of $V$. salmonicida were significantly inhibited in in vitro assays that simulated host innate defenses. Taken together, the proteomic approach allowed us to identify large numbers of proteins that are expressed by $V$. salmonicida, facilitating hypothesis driven research in order to support possible roles for some of these proteins in virulence. 


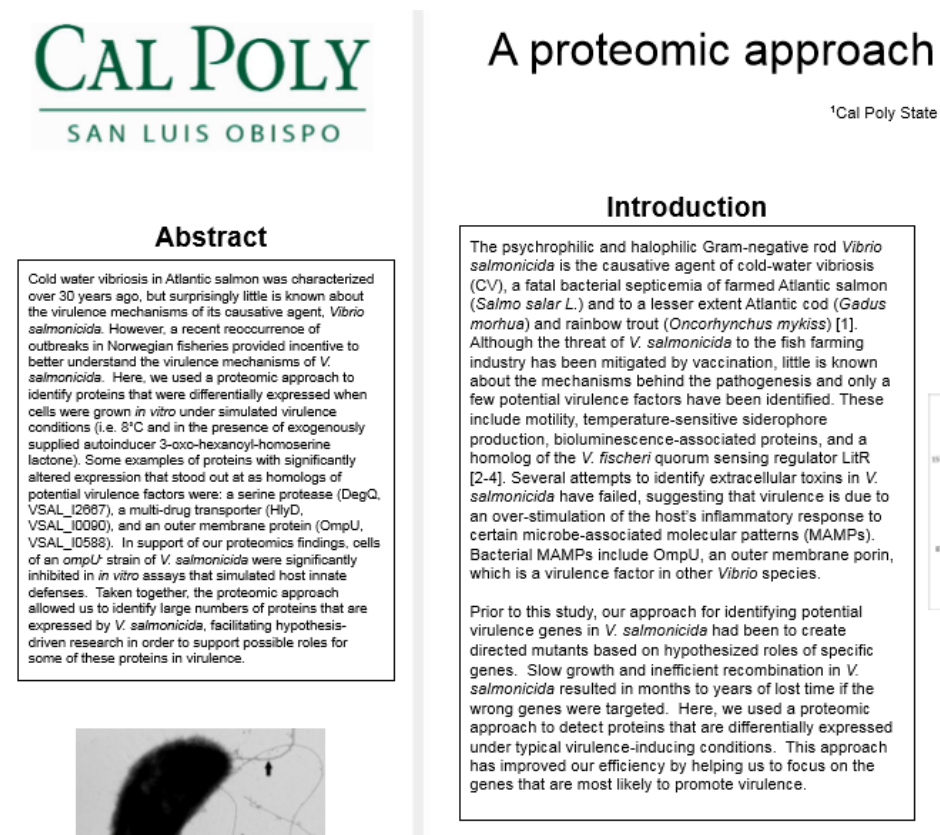

Methods and materials

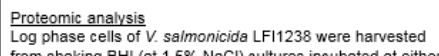
from shaking BHI (at $1.5 \%$ NaCl) cutures incubated at either 8 or $15^{\circ} \mathrm{C}$, with or without added $200 \mathrm{nM}$ 3-oxo-hexan
homoserine lactone. Total proteins were purified and

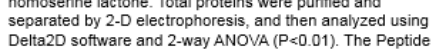
Delta2D software and 2-way ANOVA $(P<0.01)$. The Peptide
Mass Fingerprint of proteins was determined using a MALDTOF-TOF mass spectrometer. Proteins with significa changes in expression due to temperature and/or
autoinducer were identified using Mascot software and Vibrio
sandion Construction of an OmoU'-strain of V. salmonicida LF 1238 A Campenell mutation was generated by insertion of the
suicidal vector pES 122 into omp $U$ to make the OmpU coniugating ompl into the mutant using shetle vector pVSV105 in order to make the $\mathrm{OmpU}^{*}$ strain

Serum, bile, and antimicrobial peptide sensitivity $L$ L. saimonicicid cells were harvested from shaking LB broth (at $1 \% \mathrm{NaCl}$ ) cuttures incubated at $8^{\prime} \mathrm{C}$. Cells were fetal bovine serum, polymyxin B, or bovine bile. After a
period of fincubation, dilutions of each were plated on blood agar (at 2.5\% NaCl) to estimate survivorship to understanding virulence in Vibrio salmonicida Chris Massey'; Ane Mohn Bjellandz; Henning Sorumz; Pat M. Fidopiastis'
University, San Luis Obispo, CA ${ }^{2}$ Norwegian School of Veterinary Science, Osio, Norway

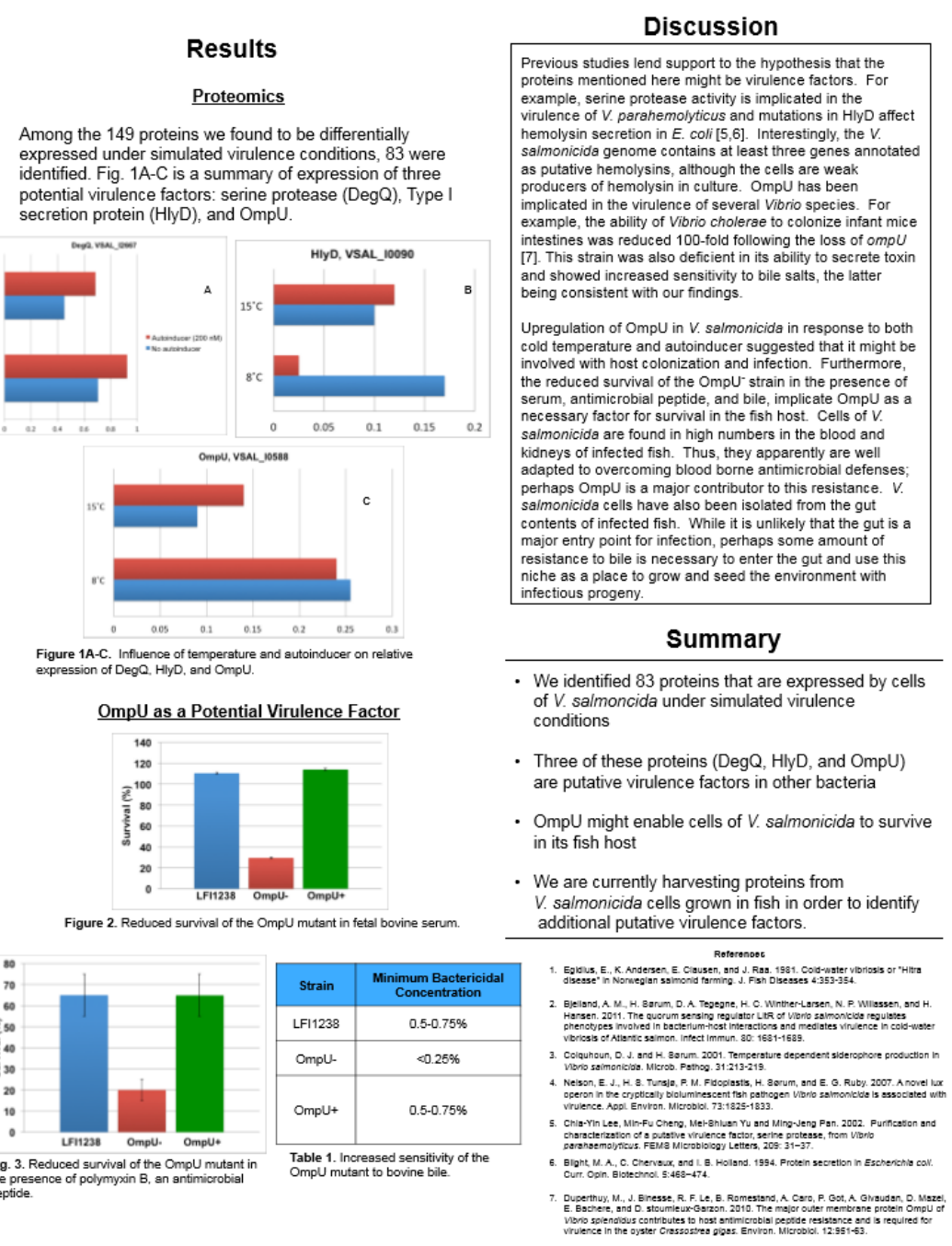

